\title{
Prediction of genetic gains by selection indices using mixed models in elephant grass for energy purposes
}

\author{
V.B. Silva ${ }^{1}$, R F. Daher ${ }^{1}$, M.S.B. Araújo ${ }^{2}$, Y.P. Souza ${ }^{2}$, S. Cassaro ${ }^{1}$, \\ B.R.S. Menezes ${ }^{3}$, L.M. Gravina ${ }^{1}$, A.A.C. Novo ${ }^{1}$, F.D. Tardin ${ }^{4}$ and \\ A.T. Amaral Júnior ${ }^{2}$ \\ ${ }^{1}$ Laboratório de Engenharia Agrícola, \\ Universidade Estadual do Norte Fluminense Darcy Ribeiro, \\ Campos dos Goytacazes, RJ, Brasil \\ ${ }^{2}$ Laboratório de Melhoramento Genético Vegetal, \\ Universidade Estadual do Norte Fluminense Darcy Ribeiro, \\ Campos dos Goytacazes, RJ, Brasil \\ ${ }^{3}$ Departamento de Genética, Universidade Federal Rural do Rio de Janeiro, \\ Seropédica, RJ, Brasil \\ ${ }^{4}$ Empresa Brasileira de Pesquisa Agropecuária, Embrapa Agrossilvipastoril, \\ Sinop, MT, Brasil \\ Corresponding author: V.B. Silva \\ E-mail: verabritosl@hotmail.com
}

Genet. Mol. Res. 16 (3): gmr16039781

Received July 17, 2017

Accepted August 30, 2017

Published September 27, 2017

DOI http://dx.doi.org/10.4238/gmr16039781

Copyright $\left({ }^{\circ} 2017\right.$ The Authors. This is an open-access article distributed under the terms of the Creative Commons Attribution ShareAlike (CC BY-SA) 4.0 License.

\begin{abstract}
Genetically improved cultivars of elephant grass need to be adapted to different ecosystems with a faster growth speed and lower seasonality of biomass production over the year. This study aimed to use selection indices using mixed models (REML/BLUP) for selecting families and progenies within full-sib families of elephant grass (Pennisetum purpureum) for biomass production. One hundred and twenty full-sib progenies were assessed from 2014 to 2015 in a randomized block design with three replications. During this period,
\end{abstract}

Genetics and Molecular Research 16 (3): gmr16039781 
the traits dry matter production, the number of tillers, plant height, stem diameter, and neutral detergent fiber were assessed. Families 3 and 1 were the best classified, being the most indicated for selection effect. Progenies 40, 45, 46, and 49 got the first positions in the three indices assessed in the first cut. The gain for individual 40 was $161.76 \%$ using Mulamba and Mock index. The use of selection indices using mixed models is advantageous in elephant grass since they provide high gains with the selection, which are distributed among all the assessed traits in the most appropriate situation to breeding programs.

Key words: Pennisetum purpureum Schum; Energy matrix; Selection index; Mixed models

\section{INTRODUCTION}

The need for innovations for the energy matrix in Brazil and the world means that more and more alternatives are being sought for clean energy. Energy produced from biomass is renewable and less polluting, and tropical forage grasses are options to obtain this energy (Daher et al., 2014; Menezes et al., 2015). From the socio-economic point of view, the insertion of these crops as renewable energy sources could contribute to agribusiness, diversifying the economy and creating jobs (Oliveira et al., 2015).

In Brazil, elephant grass (Pennisetum purpureum Schum.) has been prominent due to its higher dry matter accumulation and high fiber content. According to Morais et al. (2009), this crop is efficient in $\mathrm{CO}_{2}$ fixation, being able to accumulate more than $60 \mathrm{mg} / \mathrm{ha}$ dry matter per year under ideal conditions. Besides, some morphological elephant grass traits are highly correlated with biomass production such as stem diameter, the number of tillers, leaf blade width, height, and dry matter production.

The Darcy Ribeiro State University of Northern Rio de Janeiro (UENF) has an elephant grass-breeding program aiming at identifying genotypes with potential use for biomass and simultaneously adapted to northern and northwestern Rio de Janeiro. The program started with morphological and molecular characterization (de Lima et al., 2011; Oliveira et al., 2014) and subsequently with crossing (Silva et al., 2014; Menezes et al., 2015, 2016) of genotypes from the elephant grass germplasm bank of the UENF.

However, simultaneous assessments of several traits are common in breeding programs (Silva and Viana, 2012), as in elephant grass. Therefore, selection based on one or a few traits may generate undesirable changes due to negative genetic correlations between them (Cruz et al., 2014). An alternative is the use of selection indices, which use multivariate techniques to associate information related to several traits of agronomic interest in genetic properties from the population assessed (Krause et al., 2012). Moreover, the use of selection indices allows obtaining gain for more than one character at a time, obtaining, more quickly, genotypes with patterns suitable for different traits (Piepho et al., 2008).

Furthermore, an alternative for using index construction that results in a more accurate selection is the estimation of variance components by the restricted maximum likelihood (REML) and prediction of genetic values by the best linear unbiased predictor (BLUP) (Resende, 2002). The selection index using predicted genetic values and mixed models allow progenies to be classified according to their genetic value. Predicted genetic values of several

Genetics and Molecular Research 16 (3): gmr16039781 
auxiliary traits can be used to construct a selection index for each trait, incorporating economic weights and genetic covariance between traits (Viana and Resende, 2014). However, the use of selection index by mixed models is unknown in elephant grass families.

This study aimed to use selection indices by mixed models (REML/BLUP) for prediction of genetic gains in full-sib families of elephant grass and to select the best families and progenies for biomass production.

\section{MATERIAL AND METHODS}

Eight elephant grass accessions belonging to the germplasm bank of the UENF, previously selected as described by de Lima et al. (2011), were used as female genitors (IJ7139, CPAC, and IAC-Campinas) and male genitors (Cameroon, Cubano Pinda, BAG-86, Capim cana D'Africa, and Vrukwona). Manual crossings were performed according to Silva et al. (2014), pollen grains of elephant grass genotypes (male genitor) were collected in paper bags and then brought to female genotypes when their inflorescences, duly protected with a paper bag, had receptive stigmas. Emasculate process was not needed because of protogyny (Passos et al., 2005). The crossing was carried out between 8:00 and 10:00 am in 2013.

The experiment was carried out at the experimental station of the Centro Estadual de Pesquisa em Agroenergia e Aproveitamento de Resíduos, Pesagro-RJ (State Research Center in Agroenergy and Waste Reuse), in Campos dos Goytacazes, northern Rio de Janeiro State, Brazil. The area is located at the geographical coordinates $21^{\circ} 19^{\prime} 23^{\prime \prime} \mathrm{S}$ and $41^{\circ} 19^{\prime} 40^{\prime \prime} \mathrm{W}$, with an altitude of $20 \mathrm{~m}$ and regional climate classified as Aw, according to Koppen's classification. Soil is classified as a dystrophic Argisol (Embrapa, 2006), with the following $\mathrm{pH}: \mathrm{CaCl}_{2}=$ 6.0 and phosphorus $=11 \mathrm{mg} / \mathrm{dm}^{3} ;$ potassium $=3.2 \mathrm{mmol} / \mathrm{dm}^{3} ;$ calcium $=46.8 \mathrm{mmol} / \mathrm{dm}^{3}$; magnesium $=22.5 \mathrm{mmol} / \mathrm{dm}^{3} ;$ aluminum $=0.0 \mathrm{cmol}_{\mathrm{c}} / \mathrm{dm}^{3} ;$ hydrogen + aluminum $=21.2$ $\mathrm{mmol} / \mathrm{dm}^{3}$, and carbon $=12.3 \mathrm{~g} / \mathrm{dm}^{3}$.

After manual crossing between genitors and harvesting of hybrid seeds, hybrids were sown in 128-cell Styrofoam trays filled with forest substrate. Seedlings were transplanted to the field when they reached a height of $20 \mathrm{~cm}$, about 40 days after germination, in December 2013.

One hundred and twenty full-sib progenies derived from the crossing were planted in the field experiment in a randomized complete block design with three replications and five plants per plot, spaced $1 \mathrm{~m}$ between and within planting rows. The evaluations were carried out in two periods (cuts), the first cut made after 12 months of sowing (2014), and the second cut 8 months after the first (2015). According to Rengsirikul et al. (2011), biomass yield, growth components, and chemical composition decreased after a 12-month interval of dry matter in elephant grass.

The assessed traits were those correlated with the dry matter production (Menezes et al., 2014): number of tillers (NT) obtained by counting the number of tillers from individual plants, moments before the harvest for evaluation; stem diameter (SD, $\mathrm{cm}$ ) taken from three plants from each clump, measured $10 \mathrm{~cm}$ above the soil level with a digital caliper; plant height $(\mathrm{PH}, \mathrm{m})$ measured in three random plants from each clump with a graduated ruler. The biomass quality traits were assessed at the Laboratory of Animal Science of Universidade Estadual do Norte Fluminense Darcy Ribeiro (LZO/UENF): dry matter yield (DMY), estimated from the percentage of dry matter and the weight of tillers from individual plants, and percentage of neutral detergent fiber (\%NDF) was carried out as described by Mertens (2002), using the Ankom ${ }^{\circledR}$ Filter Bag Technique.

Genetics and Molecular Research 16 (3): gmr16039781 
Selection index analyses using REML/BLUP were performed by using the Computerized Genetic Selection - SELEGEN-REML/BLUP program, as described by Resende (2007a). The model used was the 101:

$$
\mathrm{y}=\mathrm{Xr}+\mathrm{Zg}+\mathrm{Wp}+\mathrm{e}
$$

where $y$ is the data vector, $r$ is the vector of repetition effects (assumed to be fixed) added to the overall average, $g$ is the vector of individual genotypic effects (assumed to be random), $p$ is the vector of plot effects, and $e$ the vector of errors or residuals (random). $X, Z$, and $W$ are the known incidence matrices formed by values 0 and 1 , which associates the unknown ones $\mathrm{r}, \mathrm{g}$, and $\mathrm{p}$ to the data vector $\mathrm{y}$, respectively.

Selection indices were obtained using three approaches (Viana and Resende, 2014): a) additive index, in which the relative economic importance or character weights are provided; b) multiplicative index, in which the aggregate genotypic refers to the product of traits; c) mean rank index, adapted from Mulamba and Mock (1978), in which genotypic values are classified for each character and the average of rankings of each genotype for all traits are presented as final result. Economic weights were established respecting the proportionality of relative economic values of traits involved.

According to Cruz et al., (2014), the index proposed by Mulamba and Mock is characterized by eliminating the need to establish relative economic weights to several traits and estimating the phenotypic and genotypic variances and covariance. The multiplicative index is constructed by multiplying the standardized values of each assessed character.

The selection of classic indices (CI), multiplicative indices (MI), and based on the mean of ranks (MR) or Mulamba and Mock, constructed using REML/BLUP methodology, was summarized as follows:

$$
\begin{aligned}
& \mathrm{CI}=((\text { pvar1 }) \times(\text { GVvar } 1))+((\text { pvar } 2) \times(G V v a r 2))+((\text { pvar } 3) \times(G V v a r 3)) \\
& \mathrm{MI}=(\text { GVvar1 }) \times(\text { GVvar } 2) \times(\text { GVvar } 3) \\
& \mathrm{MR}=(\text { rGVvar } 1)+(\text { rGVvar } 2)+(\text { rGVvar } 3)
\end{aligned}
$$

where $p$ is the economic weight established for the character, $G V$ is the predicted genotypic value, and $r$ is the genotype rank.

These indices are obtained as linear combinations of measures of several traits; being able to be efficient since they allow the assessment of all available information, attribute different weights to the studied traits, and attribute values judged of greater importance by the researcher (Resende, 2007b; Viana and Resende, 2014).

\section{RESULTS AND DISCUSSION}

Genetic gains predicted by indices using RELM/BLUP in elephant grass full-sib families assessed in two cuts for dry matter production, the number of tillers, plant height, stem diameter, and neutral detergent fiber are shown in Table 1.

Family 3 was the best ranked by the three indices in both cuts when considering the eight families assessed, showing the highest gains in percentage by Mulamba and Mock index, with $60.71 \%$ for cut 1 and $181.25 \%$ for the second cut. This indicates that this family increases

Genetics and Molecular Research 16 (3): gmr16039781 
the chance of success in elephant grass breeding programs for biomass production since they presented higher gains in the three indices and predictability in both cuts.

Table 1. Ranked and prediction of genetic gains of eight full-sib families of elephant grass using the classical index (CI), the multiplicative index (MI), and the Mulamba and Mock index (MM) by RELM/BLUP in both cuts.

\begin{tabular}{|c|c|c|c|c|c|c|c|c|}
\hline \multicolumn{9}{|c|}{ First cut } \\
\hline & \multicolumn{3}{|c|}{$\mathrm{CI}$} & \multicolumn{2}{|c|}{ MI } & \multicolumn{3}{|c|}{ MM } \\
\hline Rank & Family & Gain & Gain (\%) & Family & Gain (\%) & Family & Gain & Gain (\%) \\
\hline 1 & 3 & 175.93 & 0.25 & 3 & 47.76 & 3 & 2.80 & 60.71 \\
\hline 2 & 1 & 175.72 & 0.13 & 8 & 28.62 & 8 & 3.40 & 32.35 \\
\hline 3 & 5 & 175.64 & 0.09 & 1 & 22.18 & 1 & 3.73 & 20.54 \\
\hline 4 & 8 & 175.61 & 0.07 & 2 & 18.41 & 2 & 3.90 & 15.38 \\
\hline 5 & 7 & 175.58 & 0.05 & 5 & 12.93 & 5 & 4.00 & 12.50 \\
\hline 6 & 2 & 175.56 & 0.04 & 4 & 8.52 & 7 & 4.10 & 9.76 \\
\hline 7 & 6 & 175.53 & 0.02 & 6 & 4.09 & 4 & 4.29 & 5.00 \\
\hline 8 & 4 & 175.49 & 0 & 7 & 0 & 6 & 4.50 & 0 \\
\hline \multicolumn{9}{|c|}{ Second cut } \\
\hline & \multicolumn{3}{|c|}{ CI } & \multicolumn{2}{|c|}{ MI } & \multicolumn{3}{|c|}{ MM } \\
\hline Rank & Family & Gain & Gain (\%) & Family & Gain (\%) & Family & Gain & Gain (\%) \\
\hline 1 & 3 & 16.50 & 4.37 & 3 & 72.80 & 3 & 1.60 & 181.25 \\
\hline 2 & 5 & 16.23 & 2.64 & 2 & 39.58 & 5 & 2.70 & 66.67 \\
\hline 3 & 1 & 16.11 & 1.91 & 1 & 28.12 & 1 & 3.13 & 43.62 \\
\hline 4 & 7 & 16.02 & 1.33 & 5 & 18.49 & 2 & 3.45 & 30.43 \\
\hline 5 & 4 & 15.96 & 0.93 & 7 & 11.77 & 7 & 3.68 & 22.28 \\
\hline 6 & 2 & 15.92 & 0.65 & 4 & 7.10 & 4 & 3.90 & 15.38 \\
\hline 7 & 6 & 15.87 & 0.35 & 8 & 3.34 & 8 & 4.23 & 6.42 \\
\hline 8 & 8 & 15.81 & 0 & 6 & 0 & 6 & 4.50 & 0 \\
\hline
\end{tabular}

Family 1 was classified in second by the classic index in the first cut, with a gain of $0.13 \%$, whereas, in the second cut, this family was classified in third by classic $(1.91 \%)$, multiplicative (28.12\%), and Mulamba and Mock (43.62\%) indices. This allows inferring that the different ages influenced biomass production, being observed a higher percentage of gains at 8 months old after the first cut.

Family 6 presented the worst classification, with null gains by the multiplicative index in the first cut, and Mulamba and Mock in both cuts. Therefore, this family did not contribute to the indication of genotypes to be selected by the BLUP method. This method automatically eliminates families with negative genotype effect, i.e., those families with genotype effect lower than the general experiment mean. This is reasonable when the probability considered is too low to obtain a superior individual in these families.

Regarding percentage gains, the indices were able to provide considerable gains, highlighting an excellent selective potential among families for all traits assessed. Carias et al. (2016) and Pereira et al. (2014) assessed genetic gains predicted by different selection indices by the REML/BLUP methodology in a coffee breeding program and obtained satisfactory results.

Of the 120 progenies assessed, 18 had the best genetic gains through additive, multiplicative, and Mulamba and Mock indices by the REML/BLUP methodology in both cuts (Tables 2 and 3 ).

Progenies 40, 45, 46, and 49 had the first positions for the three indices assessed in the first cut. Individual 40 presented gains of $161.76 \%$ using the Mulamba and Mock index. This may indicate that index estimation using mixed models is an important strategy to identify progenies with high genotypic values, contributing to the advancement of breeding programs.

At 8 months old after the first cut, progenies 4 and 11 were selected for multiplicative and Mulamba and Mock indices, suggesting good selection possibilities for producing elephant 
grass cultivars for biomass production. Pedrozo et al. (2009) compared the efficiency of three selection indices by the REML/BLUP methodology in sugarcane populations and concluded that multiplicative index presented the highest efficiency for selection in this culture.

Table 2. Ranked and prediction of genetic gains of the best 18 full-sib progenies of elephant grass using the classical index (CI), the multiplicative index (MI), and the Mulamba and Mock index (MM) by RELM/BLUP in the first cut.

\begin{tabular}{l|c|c|c|c|c|c|c|c}
\hline & \multicolumn{3}{|c|}{ CI } & \multicolumn{2}{|c}{ MI } & \multicolumn{3}{c}{ MM } \\
\hline Rank & Progeny & Gain & Gain (\%) & Progeny & Gain (\%) & Progeny & Gain & Gain (\%) \\
\hline 1 & 40 & 15.02 & 4.43 & 40 & 32.86 & 46 & 17.00 & 161.76 \\
\hline 2 & 49 & 14.92 & 3.72 & 49 & 26.07 & 45 & 18.20 & 144.51 \\
\hline 3 & 46 & 14.87 & 3.36 & 78 & 23.42 & 66 & 18.80 & 136.70 \\
\hline 4 & 45 & 14.84 & 3.15 & 45 & 21.92 & 73 & 19.35 & 129.97 \\
\hline 5 & 78 & 14.82 & 3.01 & 46 & 20.99 & 49 & 19.72 & 125.66 \\
\hline 6 & 72 & 14.79 & 2.83 & 72 & 20.06 & 40 & 20.53 & 116.72 \\
\hline 7 & 83 & 14.77 & 2.68 & 77 & 19.26 & 62 & 21.29 & 109.06 \\
\hline 8 & 77 & 14.75 & 2.56 & 83 & 18.42 & 52 & 21.88 & 103.43 \\
\hline 9 & 23 & 14.74 & 2.45 & 7 & 17.60 & 48 & 22.36 & 99.06 \\
\hline 10 & 7 & 14.73 & 2.36 & 4 & 16.63 & 83 & 22.74 & 95.69 \\
\hline 11 & 28 & 14.71 & 2.26 & 28 & 15.78 & 7 & 23.15 & 92.26 \\
\hline 13 & 58 & 14.70 & 2.15 & 79 & 15.03 & 63 & 23.70 & 87.76 \\
\hline 14 & 47 & 14.68 & 2.07 & 47 & 14.35 & 72 & 24.18 & 84.00 \\
\hline 15 & 66 & 14.67 & 1.99 & 23 & 13.72 & 2 & 24.66 & 80.48 \\
\hline 16 & 79 & 14.66 & 1.92 & 66 & 13.18 & 78 & 25.08 & 77.43 \\
\hline 17 & 63 & 14.65 & 1.86 & 48 & 12.67 & 19 & 25.49 & 74.60 \\
\hline 18 & 2 & 14.65 & 1.81 & 73 & 12.19 & 55 & 25.87 & 72.01 \\
\hline
\end{tabular}

Table 3. Ranked and prediction of genetic gains of the best 18 full-sib progenies of elephant grass using the classical index (CI), the multiplicative index (MI), and the Mulamba and Mock index (MM) by RELM/BLUP in the second cut.

\begin{tabular}{l|c|c|c|c|c|c|c|c}
\hline & \multicolumn{3}{|c|}{ CI } & \multicolumn{2}{|c}{ MI } & \multicolumn{3}{c}{ MM } \\
\hline Rank & Progeny & Gain & Gain (\%) & Progeny & Gain (\%) & Progeny & Gain & Gain (\%) \\
\hline 1 & 4 & 27.11 & 1.92 & 4 & 28.20 & 4 & 10.00 & 343.00 \\
\hline 2 & 11 & 27.05 & 1.69 & 6 & 26.98 & 11 & 12.00 & 269.17 \\
\hline 3 & 75 & 27.03 & 1.61 & 15 & 23.58 & 49 & 12.87 & 244.30 \\
\hline 4 & 79 & 27.01 & 1.56 & 40 & 21.76 & 75 & 13.85 & 219.86 \\
\hline 5 & 6 & 27.00 & 1.52 & 49 & 20.54 & 79 & 14.64 & 202.60 \\
\hline 6 & 49 & 27.00 & 1.49 & 7 & 19.71 & 84 & 15.43 & 187.04 \\
\hline 7 & 84 & 26.99 & 1.46 & 75 & 19.07 & 77 & 16.20 & 173.46 \\
\hline 8 & 47 & 26.97 & 1.41 & 79 & 18.59 & 45 & 17.00 & 160.59 \\
\hline 9 & 45 & 26.96 & 1.38 & 11 & 18.10 & 69 & 17.67 & 150.75 \\
\hline 10 & 14 & 26.96 & 1.35 & 45 & 17.62 & 47 & 18.32 & 141.81 \\
\hline 11 & 69 & 26.95 & 1.31 & 14 & 17.22 & 71 & 18.89 & 134.50 \\
\hline 12 & 77 & 26.94 & 1.29 & 47 & 16.82 & 6 & 19.43 & 127.96 \\
\hline 13 & 71 & 26.93 & 1.26 & 71 & 16.46 & 14 & 19.91 & 122.53 \\
\hline 14 & 67 & 26.93 & 1.24 & 83 & 16.14 & 46 & 20.37 & 117.46 \\
\hline 15 & 15 & 26.92 & 1.22 & 46 & 15.82 & 7 & 20.95 & 111.49 \\
\hline 16 & 7 & 26.92 & 1.20 & 73 & 15.53 & 53 & 21.53 & 105.81 \\
\hline 17 & 46 & 26.91 & 1.18 & 72 & 15.19 & 62 & 22.05 & 100.93 \\
\hline 18 & 40 & 26.91 & 1.15 & 84 & 14.87 & 83 & 22.54 & 96.50 \\
\hline
\end{tabular}

Indices have different principles to promote selection and to obtain clear gains (Viana and Resende, 2014). In this study, considering all estimations, the Mulamba and Mock index provided greater gains in both cuts, showing the superiority of this method for most progenies, being possible to conclude that this method is interesting for obtaining the classification of progenies. 
Amaral Júnior et al. (2010) observed better results using the Mulamba and Mock index in populations of popcorn maize when compared to the classic index. Freitas Júnior et al. (2009) also reported the superiority of this index when compared to other in the simultaneous selection for traits assessed in popcorn maize. Teixeira et al. (2012) sought to determine the most appropriate selective strategy for açaí fruit production and concluded that the Mulamba and Mock index was the most efficient to estimate gains in açaí palm.

\section{CONCLUSIONS}

The use of selection indices by mixed models is advantageous in elephant grass since they provide high selection gains, distributed among all the assessed traits, the most appropriate situation to breeding programs.

The Mulamba and Mock index provided greater gains, showing the superiority of this method for most families and progenies in elephant grass.

Families 3 and 1 and progenies 40, 46, and 49 (first cut), and 4 (second cut) were the best classified, being the most indicated for selection effect in elephant grass.

\section{Conflicts of interest}

The authors declare no conflict of interest.

\section{ACKNOWLEDGMENTS}

The authors thank Fundação Carlos Chagas Filho de Amparo à Pesquisa do Estado do Rio de Janeiro (FAPERJ) for the fellowships granted and their assistance.

\section{REFERENCES}

Amaral Júnior AT, Freitas Júnior SP, Rangel RM, Pena GF, et al. (2010). Improvement of a popcorn population using selection indexes from a fourth cycle of recurrent selection program carried out in two different environments. Genet. Mol. Res. 9: 340-347. https://doi.org/10.4238/vol9-1gmr702

Carias CMOM, Gravina GA, Ferrao MAG, Fonseca AFA, et al. (2016). Predição de ganhos genéticos via modelos mistos em progênies de café Conilon. Coffee Sci. 11: 39-45.

Cruz CD, Carneiro PCS and Regazzi AJ (2014). Modelos biométricos aplicados ao melhoramento genético: volume 2. Universidade Federal de Viçosa, Viçosa.

Daher RF, Souza LB, Gravina GA, Machado JC, et al. (2014). Use of elephant grass for energy production in Campos dos Goytacazes-RJ, Brazil. Genet. Mol. Res. 13: 10898-10908. https://doi.org/10.4238/2014.December.19.11

de Lima RS, Daher RF, Gonçalves LS, Rossi DA, et al. (2011). RAPD and ISSR markers in the evaluation of genetic divergence among accessions of elephant grass. Genet. Mol. Res. 10: 1304-1313. https://doi.org/10.4238/vol103gmr1107

Embrapa (2006). Sistema brasileiro de classificação de solos. Embrapa, Rio de Janeiro.

Freitas Júnior SDP, do Amaral Júnior AT, Rangel RM and Viana AP (2009). Genetic gains in popcorn by full-sib recurrent selection. Crop Breed. Appl. Biotechnol. 9: 1-7. https://doi.org/10.12702/1984-7033.v09n01a01

Krause W, de Souza RS, Neves LG, da Silva Carvalho ML, et al. (2012). Ganho de seleção no melhoramento genético intrapopulacional do maracujazeiro amarelo. Pesqui. Agropecu. Bras. 47: 51-57. https://doi.org/10.1590/S0100$\underline{204 X 2012000100008}$

Menezes BR, Daher RF, Gravina GDA, Amaral Júnior AT, et al. (2014). Correlações e análise de trilha em capim-elefante para fins energéticos. Agraria 9: 465-470. https://doi.org/10.5039/agraria.v9i3a3877

Menezes BR, Daher RF, Gravina GDA, Pereira AV, et al. (2015). Estimates of heterosis parameters in elephant grass

Genetics and Molecular Research 16 (3): gmr16039781 
(Pennisetum purpureum Schumach.) for bioenergy production. Chil. J. Agric. Res. 75: 395-401. https://doi. org/10.4067/S0718-58392015000500003

Menezes BR, Daher RF, Gravina GA, Silva VB, et al. (2016). Seleção de genótipos de capim-elefante (Pennisetum purpureum) utilizando a metodologia REML/BLUP. Rev. Cienc. Agrar. (Lisb.) 39: 360-365. https://doi.org/10.19084/ $\underline{\mathrm{RCA} 15073}$

Mertens DR (2002). Gravimetric determination of amylase-treated neutral detergent fiber in feeds with refluxing in beakers or crucibles: collaborative study. J. AOAC Int. 85: 1217-1240.

Morais RF, Souza BJ, Leite JM, Soares LHB, et al. (2009). Elephant grass genotypes for bioenergy production by direct biomass combustion. Pesqui. Agropecu. Bras. 44: 133-140. https://doi.org/10.1590/S0100-204X2009000200004

Mulamba NN and Mock JJ (1978). Improvement of yield potential of the Eto Blanco maize (Zea mays L.) population by breeding for plant traits. Egypt. J. Genet. Cytol. 7: 40-51.

Oliveira ÉS, Daher RF, Ponciano NJ, Amaral Gravina G, et al. (2015). Variation of Morpho-Agronomic and Biomass Quality Traits in Elephant Grass for Energy Purposes According to Nitrogen Levels. Am. J. Plant Sci. 6: 1685. https:// doi.org/10.4236/ajps.2015.611168

Oliveira MLF, Daher RF, Gravina GDA, Silva VB, et al. (2014). Pre-breeding of elephant grass for energy purposes and biomass analysis in Campos dos Goytacazes-RJ, Brazil. Afr. J. Agric. Res. 9: 2743-2758. https://doi.org/10.5897/ AJAR2014.8900

Passos LP, Machado MA, Vidigal MC and Campos AL (2005). Molecular characterization of elephant grass accessions through RAPD markers. Cienc. Agrotec. 29: 568-574. https://doi.org/10.1590/S1413-70542005000300009

Pedrozo CA, Benites FRG, Barbosa MHP, Resende MDV, et al. (2009). Eficiência de índices de seleção utilizando a metodologia REML/BLUP no melhoramento da cana-de-açúcar. Sci. Agrar. 10: 31-36. https://doi.org/10.5380/rsa. $\underline{\mathrm{v} 10 \mathrm{i} 1.11711}$

Pereira TB, Mendes ANG, Botelho CE, Rezende JC, et al. (2014). Seleção de progênies $\mathrm{F}_{4}$ de cafeeiro obtidas de cultivares do grupo ICATU. Coffee Sci. 8: 337-346.

Piepho HP, Mohring J, Melchinger EA and Buchse A (2008). Blup for phenotypic selection in plant breeding and variety testing. Euphytica 161: 209-228. https://doi.org/10.1007/s10681-007-9449-8

Rengsirikul K, Ishii Y, Kangvansaichol K, Pripanapong P, et al. (2011). Effects of inter-cutting interval on biomass yield, growth components and chemical composition of napier grass (Pennisetum purpureum Schumach) cultivars as bioenergy crops in Thailand. Grassl. Sci. 57: 135-141. https://doi.org/10.1111/j.1744-697X.2011.00220.x

Resende MDV (2002). Genética biométrica e estatística no melhoramento de plantas perenes. Embrapa Informação Tecnológica, Brasília.

Resende MDV (2007a). Selegen-REML/BLUP: statistical system and computerized genetic selection through linear mixed models. Embrapa Florestas, Colombo.

Resende MDV (2007b). Matemática e estatística na análise de experimentos e no melhoramento genético. Embrapa Florestas, Colombo.

Silva MDM and Viana A (2012). Alternativas de seleção em população de maracujazeiro-azedo sob seleção recorrente intrapopulacional. Rev. Bras. Frutic. 34: 525-531. https://doi.org/10.1590/S0100-29452012000200026

Silva VQR, Daher RF, Gravina GA, Ledo FJS, et al. (2014). Capacidade combinatória de capim elefante com base em caracteres morfoagronômicos. Bol. Ind. Anim. 71: 63-70. https://doi.org/10.17523/bia.v71n1p63

Teixeira DHL, Oliveira MDSP, Gonçalves FMA and Nunes JAR (2012). Índices de seleção no aprimoramento simultâneo dos componentes da produção de frutos em açaizeiro. Pesqui. Agropecu. Bras. 47: 237-243. https://doi.org/10.1590/ S0100-204X2012000200012

Viana AP and Resende MDV (2014). Genética quantitativa no melhoramento de fruteiras. Interciência, Rio de Janeiro.

Genetics and Molecular Research 16 (3): gmr16039781 